\title{
Application of Mesh-free Methods in Transient Dynamic Analysis of Orthotropic Plates
}

Josef Soukup ${ }^{1}$, Milan Žmindák ${ }^{2}$, Jan Skočilas ${ }^{3}$, Lenka Rychlíková ${ }^{1}$

${ }^{1}$ Faculty of Production Technology and Management, J. E. Purkyne University in Usti nad Labem. Pasteurova 3334/7, 40001 Usti nad Labem. Czech Republic. E-mail: soukupj@fvtm.ujep.cz, rychlikova@fvtm.ujep.cz

${ }^{2}$ Faculty of Mechanical Engineering, University of Zilina, Slovak Republik. E-mail: milan.zmindak@fstroj.uniza.sk

${ }^{3}$ Faculty of Mechanical Engineering, Czech Technical University in Prague, Czech Republic. E-mail: jan.skocilas@fs.cvut.cz

The requirements for reducing the weight and increasing the strength and carrying capacity of the plane and space structures are constantly growing. The one of the way how to meet demands is to use the layered shell composite structures. They could be applied not only in mechanical engineering (containers, pressure vessels, etc.) but also in the civil engineering (cooling towers, roofs, etc.). The article deals with computation procedure of shell and plates using meshless methods. A mesh-free local Petrov-Galerkin (MLPG) method is applied to solve laminate plate problems described by the Reissner-Mindlin theory. Two projection methods are developed to generate the shell surface using the Lagrangian mesh-free interpolations. The bending moment and the shear force expressions are obtained by integration through the laminated plate for the considered constitutive equations in each lamina. The Reissner-Mindlin theory reduces the original three-dimensional (3-D) thick plate problem to a two-dimensional (2-D) problem. Results of transient dynamic loads in the composite plates using MLPG solution are presented here.

Keywords: Composite Materials, Mesh-free Methods, Transient Dynamics, Orthotropic Plates.

\section{Acknowledgement}

This work has been supported by grant SGS - Internal Agency of University of Jan Evangelista Purkyně in Ústí nad Labem and by the Slovak Grant Agency VEGA 1/1226/12.

\section{References}

[1] REDDY J.N. (1997). Mechanics of Laminated Composite Plates, Theory and Analysis. CRC Press, Boca Raton.

[2] ALTENBACH, H., ALTENBACH, J., KISSING. W. (2001), Structural analysis of laminate and sandwich beams and plates. Lublin.

[3] BATHE, K.J. (1996). Finite Element Procedures, Prentice Hall, Inc. 1996.

[4] ŽMINDÁK, M., MEŠKO, J., PELAGIĆ, Z., ZRAK, A., In: Finite Element Analysis of Crack Growth in Pipelines, Manufacturing Technology, Vol. 14, No. 1, pp. 116-122.

[5] BREZNIČAN, M., FABIAN, P., MEŠKO, J., DRBÚL, M. (2013). The simulation of influence of Quenching Temperature no properties of Bearing Rings. Manufacturing Technology, Vol. 13, No.1, pp.20-25.

[6] MIČIAN, M., PATEK, M., SLÁDEK, A. (2014): Concept of Repairing Branch Pipes on High- Pressure Pipelines by using Split Sleeve. Manufacturing Technology, Vol. 14, No.1, pp. 60-66.

[7] JAKUBOVIČOVÁ, L., SÁGA, M., VAŠKO, M.(2013). Impact Analysis of Mutual Rotation of Roller Bearing Rings on the Process of Contact Stresses in Rolling Elements. Manufacturing Technology, Vol. 13,No.1, pp. 5054.

[8] KORMANíKOVÁ, E., KOTRASOVÁ, K. (2011). Elastic Properties of Fiber Reinforced Composite Materials. Chem. Listy 105, pp- 758-762

[9] DVORKIN, E., BATHE, K. J. (1984). A continuum mechanics based four-node shell element for general nonlinear analysis. Engineering Computations, 1, pp. 77-78.

[10] CHAMPELLE, D. , BATHE, K.J. (2003). The finite Element Analysis of shells-fundamentals. Springer-Verlag Berlin Heidelberg.

[11] ANTES, H. (1981), On boundary integral equation formulation for elastic shallow shell bending problems. In Boundary Element Methods (Brebbia C.A., ed.), Springer, Berlin.

[12] SLADEK, J., SLADEK, V, HELLMICH, CH., EBERHARDSTEINER, J. (2007), Analysis of thick functionally graded plates by local integral equation method. Communications in Numerical Methods in Engineering, Vol. 23, No. 8, s. 733-754. 
[13] WANG J., HUANG M (1991). Boundary element method for orthotropic thick plates. Acta Mechanica Sinica 1991; 7: 258-266.

[14] BESKOS D.E. (1991), Static and dynamic analysis of shells. In Boundary Element Analysis of Plates and Shells (Beskos D.E. ed.). Springer-Verlag: Berlin, s. 93-140.

[15] SLADEK, J.; SLADEK, V.; MANG, H.A. (2003). Meshless LBIE formulations for simply supported and clamped plates under dynamic load. Computers and Structures, 81, pp.1643-1651

[16] ŽMINDÁK, M., RIECKY, D.: Meshless modelling of Laminate Mindlin Plates under dynamic loads. Communications, 3/2012, pp. 24-31.

[17] ATLURI, S. N.- SHEN, S. (2002). The Mesh-free Local Petrov-Galerkin (MLPG) Method. Tech Science Press.

[18] ATLURI, S. N. (2004), The Meshless Method (MLPG) For Domain \& BIE Discretizations. Tech Science Press.

[19] BELYTSCHKO, T.; KROGAUZ, Y.; ORGAN, D.; FLEMING, M.; KRYSL, P. (1996). Meshless methods; an overview and recent developments. Comp. Meth. Appl. Mech. Engn., 139, s.3-47.

[20] SORIC, J. - LI, Q. - ATLURI, S.N. (2004), Meshless local Petrov-Galerkin (MLPG) formulation for analysis of thick plates. CMES: Computer Modeling in Engineering \& Sciences, 6, s. 349-357.

[21] LONG, S.Y. , ATLURI, S.N. (2002), A meshless local Petrov Galerkin method for solving the bending problem of a thin plate. CMES: Computer Modeling in Engineering \& Sciences, 3, s.11-51.

[22] SLADEK, J., SLADEK, V., MANG, H.A. (2002), Meshless formulations for simply supported and clamped plate problems. Int. J. Num. Meth. Engn., 55, pp. 359-375.

[23] LANCASTER, P., SALKAUSKAS, K. (1981): Surfaces generated by moving least squares methods, Math. Comput., 37, s. 141-158.

[24] CHEN, J.S., WU, C.T., YOON, S., YOU, Y.(2001). A Stabilized Conforming Nodal Integration for Galerkin Meshfree Methods. Int. J. for Num. Meth. in Engng., 50, pp.435-456.

[25] WU, C.T., GUO, Y., WANG, H.P., BOTKIN, M.E. (2011), A meshfree Analysis of Shell Structures, In: 8 th International LS-DYNA Users Conference, pp. 16-11, 16-24. 